\title{
The Corporate Interest Deduction: A Policy Evaluation
}

\author{
Alvin C. Warren, Jr.†
}

Treatment of the cost of corporate capital has been a significant conceptual and operational problem for the federal tax on corporate income throughout its history. While interest expense is currently deductible in full from corporate income, ${ }^{1}$ no deduction whatsoever is permitted for dividend payments. ${ }^{2}$ The unlimited deduction for corporate interest payments originated in 1918 as a temporary measure designed to equalize the effects of the World War I excess profits tax. ${ }^{3}$ Before 1918, only limited offsets against corporate income were granted for interest payments, ${ }^{4}$ apparently because Congress feared that cor-

$\uparrow$ Associate Professor of Law, Duke University School of Law. Visiting Associate Pro. fessor of Law, University of Pennsylvania School of Law, 1974-75. The author would like to thank Joseph Bell, Michael Gordon and Bernard Wolfman for their comments.

1. INT. Rev. CoDE of 1954, \$ 163. Special limitations on the deductibility of corporate interest apply in cases of debt-financed acquisitions ( $\$ 279)$, related taxpayers ( $\$ 267$ ), and interest relating to tax-exempt income ( $\$ \$ 264-65$ ).

2. But see INT. REv. CODE OF 1954, $\$ 247$, first enacted in Revenue Act of 1942, ch. $619, \S 133,56$ Stat. 830 , which permits public utilities to deduct dividend payments on preferred stock issued prior to October $1,1942$.

3. The wartime revenue measure imposed a tax on corporate "cxcess profits," with an "excess profits credit" (an amount of income not subject to this tax) for a specified return on "invested capital." Revenue Act of 1918, ch. 18, $\$ \S 300-28,40$ Stat. 1057. As borrowed money was excluded from the definition of invested capital, Congress thought it was "only fair" that interest on corporate indebtedness be fully deductible. H.R. REP. No. 767, 65th Cong., 2d Sess. 12-13 (1918); Revenue Act of 1918, ch. 18, $\$ 234$ (a)(2), 40 Stat. 1077.

4. An interest deduction for corporations was allowed when corporate income was taxed briefly in 1894, Act of Aug. 27, 1894, ch. 349, $\$ 32,28$ Stat. 556; but that levy, along with the individual income tax, was ruled unconstitutional in Pollock v. Farmers' Loan \& Trust Co., 158 U.S. 601 (1895). The Corporate Excise Tax of 1909, which introduced the 20th century tax on corporate income, permitted deduction of interest only on an amount of indebtedness equal to a corporation's capital stock. Act of Aug. 5, 1909 , ch. $6, \$ 38(2 e), 36$ Stat. 113. When the individual income tax was enacted in 1913, a process of increasing interest deductibility for corporations was begun, though no reason was given for the change. But see Hearings on H.R. 3321 Before the Senate Comm. on Finance, 63d Cong., lst Sess. 2058.61 (1913) (brief by Walker D. Hines); id. at 2078 (bricf by J.T. Clark). Interest could now be deducted on indebtedness equal to one half the sum of outstanding stock and debt. Act of Oct. 3, 1913, ch. 16, \$ II G (b), 38 Stat. 172-73. The limitation was held constitutional. Tyee Realty Co. v. Anderson, 240 U.S. 115,118 (1916).

The Revenue Act of 1916, ch. 463, $\$ 12(3 \mathrm{~d}), 39$ Stat. 768 , permitted a deduction for interest on debt equal to the sum of the total paid-up stock and one half of the outstanding interest-bearing indebtedness. The 1913 limitation was criticized both in the 1916 hearings and on the floor of the House because of the confusion it generated, 53 CoNG. REC. 10656 (1916) (remarks of Rep. Sherley); Hearings on H.R. 16763 Before the Senate Comm. on Finance, 64th Cong., lst Sess. 75 (1916) (statement of Alfred Thom), 
porations would try to avoid taxation by substituting bonds for stock. When the excess profits tax was repealed in 1921, the full interest deduction was retained as part of the corporate income tax, without any explanation by Congress in the legislative history. ${ }^{\circ}$

Legal commentary on interest and dividend deductibility has concentrated on refining the statutory distinction between debt and equity capital, ${ }^{\top}$ while economic analysis has been preoccupied with the effects of differential treatment. ${ }^{8}$ This article inquires, more fundamentally, whether the corporate interest deduction is justified as a matter of policy; ${ }^{9}$ it assumes that nondeductibility of dividends is firmly entrenched in the tax structure. ${ }^{10}$

\section{Defining the Corporate Entity}

Congress has chosen to regard the corporation as a taxable entity under the current tax system, but that choice is only the beginning of

and its theoretical applicability to an excise, rather than an income, tax also prompted criticism. Id. The 1916 limitation was held constitutional in Brushaber v. Union Pac. R.R., 240 U.S. 1, 23 (1916), and was continued by the War Revenue Act of 1917, ch. $63, \$ 1207(\mathrm{I}), 40$ Stat. 334.

5. 44 Cong. Rec. 4007 (1909) (remarks of Sen. Root). See also 53 Cong. Rec. 10656 (1916) (remarks of Rep. Sherley); R. Blakey \& G. Blakey, The Frderal Income Tax 46 (1940).

6. The Revenue Act of 1921, ch. 136, $\$ \S 300-38,42$ Stat. 271-77, repealed the excess profits tax as of January 1, 1922.

7. See Bittker, Thin Capitalization: Some Current Questions, 34 TAxes 830 (1956) (revised version in 10 U. FLA. L. REv. 25 (1957)); Caplin, The Caloric Count of a Thin Incorporation, N.Y.U. 17TH INST. ON FED. TAX. 771 (1959), 43 MARQ. L. REv. 31 (1959); Goldstein, Corporate Indebtedness to Shareholders: "Thin Capitalization" and Related Problems, 16 TAX L. REv. 1 (1960); Plumb, The Federal Income Tax Significance of Corporate Debt: A Critical Analysis and a Proposal, 26 TAx L. REv. 369 (1971); Semmel, Tax Consequences of Inadequate Capitalization, 48 Colum. L. Rev. 202 (1948); Stone, Debt-Equity Distinctions in the Tax Treatment of the Corporation and Its Shareholders, 42 Tul. L. REv. 251 (1968); Note, Toward New Modes of Tax Decisionmaking-The Debt-Equity Imbroglio and Dislocations in Tax Lawmaking Responsibility, 83 HARv. L. REv. 1695 (1970).

8. See Lent, Bond Interest Deduction and the Federal Corporation Income Tax, 2 Nat'L TAX J. 131 (1949); notes 105-17 infra.

9. No attempt is made to evaluate the multitudinous other tax consequences which turn on classifying a corporate security as debt or equity. The principal factors to be considered in choosing the form in which to cast corporate capital are set out in B. BiTTKER \& J. Eustice, FEderal InCOME TAXation of Corporations and SHareiolders $\$ 4.01$ (3d ed. 1971). See also Plumb, supra note 7 , at 376 . Three of the most notable consequences under the Internal Revenue Code are: (1) Payment for debt at maturity may constitute a "reasonable need" under $\$ 533(\mathrm{a})$ and thus avoid the accumulated earnings penalty tax; (2) receipt of principal by a creditor is a tax-free recovery of basis with the amount in excess of basis taxed as capital gain under $\S 1232$, while a stock redemption may be taxed as a dividend under $\$ 302$; (3) losses incurred on the sale of corporate stock are capital losses (unless the small business provisions of $\$ \S 1242-44$ apply), while bad debts may be deductible under $\$ 166$.

While all of these consequences now turn on whether a corporate security is classified as debt or equity, there is no reason to believe that a single touchstone should ideally control such a variety of tax issues. Rather, each provision should presumably be analyzed in terms of its underlying statutory purpose. This article is limited to an exploration of whether the corporate interest deduction is so justified.

10. See p. 1609 infra. 
analysis. What elements constitute a corporation for the purposes of taxation? Implicit in the answer one gives to that question is a decision as to whether interest payments should be deducted from corporate income.11

Four obvious models of the corporate entity present themselves, each representing an increasingly narrowed view of corporate composition. First, the corporate entity might be identified as the aggregation of all parties (management, workers, suppliers of materials and services, suppliers of capital, and so forth) participating in the productive enterprise. Taxable corporate income would be defined as the receipts of that aggregation, with no deductions for payments to its members. Second, the corporate entity for tax purposes could be identified as the assemblage represented by corporate capital, with income defined as above, minus payments to managers, workers, and suppliers of materials and services, but payments for corporate capital would not be deductible. Third, the entity might be associated solely with the residual capital or equity of the corporation, so corporate income would be defined as in the second example, but with a deduction for the cost of debt capital. Finally, the corporate entity might be identified as what remains after payments to all participants in the enterprise. In this case, payments for equity capital would also be deductible, so the tax would be levied only on the year's undistributed earnings.

Traditional discussion of corporate structure and function implicitly adopts the third definition, thereby excluding debt capital from the corporate entity and including only residual capital or equity in the definition. Such discussion typically identifies the corporation with shareholders' equity on the grounds of proprietorship: Just as a sole proprietor owns his business, so it is said that stockholders own their corporations. ${ }^{12}$ Yet the division of ownership rights in the corporate context is now so complex as to require rejection of the simplistic notion that stockholders can be considered "the owners" of the corporation. ${ }^{13}$ Stockholders in large public corporations certainly cannot exercise ownership rights over corporate assets in the same way they can exercise control or dominion over personal assets or over the assets of business proprietorships they may also own.14 Shareholdermanagers of closely held corporations may operate more like partners,

11. See Note, supra note 7, at 1706 n.56.

12. See note 44 infra; R. Goode, The Corroration Income Tax 16-17 (1951); W. Paton, Accounting Theory 75 (1922); R. Posner, Economic Analysis of LAW 178-79 (1972).

13. R. POSNER, supra note 12 , at 179.

14. See generally A. Berle \& G. Means, The Modern Corporation and Private PROPERTY (1932). 
a possibility the Internal Revenue Code explicitly recognizes, ${ }^{15}$ but the source of their right to so operate lies as much in their managerial as their stockholder status. Corporate law assigns control of the daily operation of the business to the board of directors, not the shareholders. ${ }^{16}$ In some respects, such as the right to dispose of particular corporate assets, shareholders may actually possess fewer orwnership rights vis-à-vis the corporation than do secured debtholders. ${ }^{17}$

In short, ownership rights are divided among management and investment interests in the modern corporation..$^{18}$ Management controls the daily operation of the enterprise, while investors retain an interest in the earnings of corporate assets. Shareholders typically have a residual but junior interest in those earnings, while debtholders generally have a senior but limited interest. In addition, shareholders usually possess the right to elect the board of directors; this right may or may not give them effective control over the operations of management. ${ }^{10}$ The possibility of insolvency reorganization also gives debtholders at least a contingent voting interest. ${ }^{20}$ This division of proprietorship rights among shareholders, debtholders, and management renders the simple equation of shareholder interests and the property rights of a sole proprietor less than compelling.

More significantly, even if one were convinced that shareholders are, in some meaningful sense, the proprietors of the contemporary corporation, the relevance of that assertion to the definition of the corporate entity appropriate for taxation is far from clear. National tax policy choices cannot be preempted by the rather metaphysical conclusion that the "true nature" of the corporation is thus revealed. Nor is the assertion convincing that because income from assets owned by individuals is taxed to those individuals, so income from corporate assets should be considered the residual accruing to shareholders as the ultimate owners of the assets. That analogy begs the question.

15. INT. REV. CODE of 1954, $\$$ 1371-79 (Subchapter S), permits certain small business corporations to eliminate taxation at the corporate level, with corporate earnings taxed directly to the shareholders. Such taxation is beyond the scope of this article.

16. See generally W. CARY, Corporations 150-361 (4th ed. unabr. 1969).

17. Bonds are often secured by a mortgage or lien on specific corporate property. In the event of a default by the corporation, the bondholders' trustee can theoretically foreclose the mortgage and have the property sold. In general, such bondholder protective provisions actually operate to give the bondholders preferential treatment in bankruptcy or reorganization proceedings. See V. BRUdNEY \& M. ChIRELSTEIN, Corporate

FINANCE 109-16 (1972); W. CARY, supra note 16, at 1285-87; W. Paton, supra note 12, at 77.

18. The classic statement of this thesis is A. BERLE \& G. MEANs, supra note 14.

19. See generally Manne, Some Theoretical Aspects of Share Voting, 64 Colum. L. Rev. 1427 (1964); Manne, The "Higher Criticism" of the Modern Corporation, 62 ColvM. L. REv. 399 (1962).

20. See V. Brudney \& M. Chirelstein, supra note 17, at 119-25. 
Income from individually owned assets is taxed to the owners because the taxable unit is initially defined as the individual. Property law concepts of ownership define what belongs to each unit, but do not determine this initial designation of the taxable unit. Similarly, viewing shareholders as corporate proprietors produces property law concepts which might illuminate what belongs to the shareholders once they were selected as the appropriate unit for taxation. Such concepts do not, however, aid in that preliminary selection process.

To recapitulate, exclusion of debtholders from the corporate family ${ }^{21}$ has traditionally been defended on the basis of property law concepts of ownership. The application of those concepts to the modern corporation is at least problematic; even if accepted as a matter of fact, the ownership proposition nonetheless fails to satisfy in our context because of its essential irrelevance to the definition of the taxable unit. A more appropriate line of inquiry examines the implicit definitions of the corporate entity that arise from various concepts of corporate income to see if they explain why interest should be deducted from corporate income, while no deduction is permitted for dividends.

\section{Is There a Conceptual Mandate for Retaining the Deduction?}

\section{A. Concepts of Corporate Income}

The concept of net income is sometimes offered in justification of the corporate interest deduction. According to this argument, interest payments are as much expenses of producing income as are rent, wages, and the cost of supplies or productive assets; thus denying deductibility would make the tax pro tanto a levy on gross income.22 Dividends, on the other hand, are seen as a division of the profits of the enterprise, and not an expense of doing business. ${ }^{23}$ This distinction is sometimes supported by an analogy between corporate and noncorporate business enterprises. ${ }^{24}$

The analogy is tempting but treacherous. If a sole proprietor bor-

21. The expression is taken from W. Andrews, Federal Income Taxation If 55.21, at 862 (1969).

22. Plumb, supra note 7, at 625. See Cuyuna Realty Co. v. United States, 382 F.2d 298, 301 (Ct. Cl. 1967).

23. Jewell, The Tax Legislation Against Conglomerates-The Case Against the Tax Legislation, Conglomerate MERgers and AcQuisitions, 44 Sr. John's L. Rev. 1073, 1078-79 (spec. ed. 1970); Comment, The Debt-Equity Question in the Federal Income Taxation of Corporations: Will the New Section 385 Make Tax Planning a Reality?, 11 DuQ. L. REv. 595, 598 (1973).

24. Goldstein, supra note 7, at 1-2. 
rows capital from a bank or insurance company, his interest payments are admittedly as much a business expense as are payments for wages or rent; one might think a corporate enterprise that borrows capital should be treated no differently. This position, however, starts from the assumption that shareholder equity is the appropriate entity for corporate taxation; it implicitly adopts the third model of the corporate entity. Before accepting this model, surely one should ask whether the differences between natural persons and corporations call for different tax treatment of the two.

One such difference illustrates and previews the problem. While it is meaningful to distinguish between capital owned by an individual and capital which he borrows, that dichotomy fails to make sense in the case of a corporation since all corporate capital, whether equity or debt, involves an obligation on the part of the corporation to someone else, whether shareholder or debtholder. Payments by an individual for money borrowed to earn money reduce accretion to the individual's own wealth and are therefore deducted from the individual's gross income while the earnings of capital are included. ${ }^{25}$ On the other hand, since all the assets owned by a corporation are necessarily financed by capital contributed by someone other than the corporation, there is no corporate correlative to an individual's own wealth. Even the year's undistributed earnings represent an increase in shareholder equity. Accordingly, the deductibility of interest by individuals does not provide a rationale for such deductions by corporations.

Stripped of analogies and assumptions which prejudice the answer, the pertinent policy question is: Do concepts of corporate income mandate inclusion in the corporate tax base of payments to corporate investors with an unlimited but residual interest in corporate earnings, but exclusion of payments to investors with a limited but prior interest? Three concepts of corporate income will be examined in search of an answer: increment in value, accounting income, and income as product.

\section{Corporate Income as Increment in Value}

Recent American discussion of the appropriate base for income taxation $^{26}$ has almost uniformly taken as its reference point the Haig-

25. INT. REv. CODE of 1954, $\S 163$, also permits the deduction of interest incurred to finance personal consumption, a matter beyond the scope of this article.

26. See B. Bittker, C. Galvin, R. Musgrave \& J. Pechman, A Comprehensive INCOME TAX BAsE? A DEBATE (1968); Aaron, What is a Comprehensive Tax Base Anyway?, 22 NaT'L Tax J. 543 (1969); Andrews, Personal Deductions in an Ideal Income Tax, 86 
Simons definition of income:

Personal income may be defined as the algebraic sum of (1) the market value of rights exercised in consumption and (2) the change in the value of the store of property rights between the beginning and end of the period in question. In other words, it is merely the result obtained by adding consumption during the period to "wealth" at the end of the period and then subtracting "wealth" at the beginning. The sine qua non of income is gain, as our courts have recognized in their more lucid moments-and gain to someone during a specified time interval. Moreover, this gain may be measured and defined most easily by positing a dual objective or purpose, consumption and accumulation, each of which may be estimated in a common unit by appeal to market prices. ${ }^{27}$

Although Simons' famous formulation clearly referred to personal income, the definition has sometimes been regarded as neutral with regard to the taxable unit. ${ }^{28}$ Presumably, a corporation, as well as a natural person, might therefore have income in the Haig-Simons sense.

What are consumption and accumulation for a corporate entity? Whether consumption is defined as the "use of wealth for personal gratification (final as distinct from instrumental use)"29 or, more generally, as the destruction of economic resources, ${ }^{30}$ it is difficult to comprehend how a corporation can ever consume anything. A corporation clearly cannot enjoy a glass of beer, destroying its utility for future production. Just as obviously, the diversion of corporate funds from production to support a symphony or art gallery may simply be a form of advertising done to build corporate goodwill. When such diversions are made to bring pleasure to corporate managers, employees or investors, without regard to corporate goodwill, it is the income of the

HARv. L. REv. 309 (1972). Recent discussion of "tax expenditures" (tax benefits which are said to be the equivalent of budgetary expenditures because they are not necessary to define income) often depends on the Haig-Simons definition to provide a model of what income is, so that deviation from the ideal can be identified. See id. at 309 n.1.

27. H. Simons, Personal Income Taxation 50 (1938).

28. Pechman, Comprehensive Income Taxation: A Comment, 81 Harv. L. Rev. 63, 65 (1967). But see Bittker, Comprehensive Income Taxation: A Response, 81 HaRv. L. REv. 1032, 1038 (1968); Galvin, More on Boris Bittker and the Comprehensive Tax Base: The Practicalities of Tax Reform and the ABA's CSTR, 81 HARV. L. REV. 1016, 1017 (1968).

29. Break, Capital Maintenance and the Concept of Income, 62 J. PoL. EcoN. 48, 52 (1954). For the classic definition of income as psychic satisfaction which is imperfectly reflected by events in the physical world which, in turn, are indirectly measured by consumption expenditures, see I. Fisher, THE THEORX OF INTEREST 5-6 (1930). The Fisher definition of income as consumption leads necessarily to the conclusion that corporations are incapable of income. 1. FISHER \& H. FISHER, Constructive INCOME TAXation 28-29 (1942).

30. H. Simons, supra note 27 , at $49-50$. 
managers, employees or investors which is increased in the HaigSimons sense. The corporation's position is the same as if it had made salary or dividend payments to its managers or investors who then purchased directly whatever benefits were derived from the symphony or art gallery.

Only if a corporation made payments to an art gallery (or anyone else) neither to build corporate goodwill nor to benefit any group related to the corporation might the payment be considered consumption as a wasting of economic resources. A wage earner who, for whatever reason, destroyed half his weekly wages would still include the full amount in gross income. Is this not equivalent to a corporation which engaged in inefficient or wasteful activities? To put the question that way is to make evident the incongruity of the consumption concept in this context. Waste and inefficiency in profit-making activity are usually thought to result in less income rather than more. Corporations are organized to produce, not to destroy.

If the incongruity of the consumption concept in the corporate context is not surprising given the production role of corporations, the notion of accumulation seems at first to accord with corporate enterprise. Some corporations do grow in assets and financial power, a phenomenon which appears to be a correlative of individual aggregation of wealth. The resemblance disappears, however, on examination: For any capital accumulated by a corporation, there necessarily arises a series of obligations running from the corporation to its investors. It is therefore just as misleading to say a corporation accumulates wealth as it is to say a business proprietorship accumulates wealth. In both cases wealth is accumulated by the investors-debtholders and shareholders in the case of a corporation.

Only if we are thus prepared to define corporate income as income to corporate investors, qua corporate investors, does the Haig-Simons definition provide a workable formula: the algebraic sum of (l) distributions to investors minus advances from investors, and (2) the value of their investment at the end of the period minus its value at the beginning. ${ }^{31}$ This definition reduces to the increment in the value of the investors' interest, adjusted for capital additions or distributions. In other words, it is the investors' accumulation and consumption which is measured, since those concepts are without operational significance for a corporation as distinct from its investors.

31. See P. Hansen, The Accounting Concept of Profit 39 (2d ed. 1972); Edwards, The Nature and Measurement of Income, in STUdies IN Accounting Theory 70, 111 (2d ed. W. Baxter \& S. Davidson eds. 1962). 
Alternatively, corporate income could be defined as the increment in the value of the shareholders' interest, adjusted for capital additions or distributions. Measurement of the investors' interest in general would include interest payments in the tax base, while measurement of only the shareholders' interest would exclude them. But the HaigSimons definition provides no conceptual corollary which requires measurement of only the shareholders' equity. Nor does the objective traditionally ascribed to the corporate firm, to earn money for the shareholders, ${ }^{32}$ support the restriction since some of the money earned in implementing that goal goes to senior investors. Thus even if the essentially personal Haig-Simons definition is applied in this way to derive a concept of corporate income, ${ }^{33}$ there is no conceptual mandate for excluding interest payments from the corporate tax base. ${ }^{34}$

32. Bodenhorn, $A$ Cash-Flow Concept of Profit, 19 J. Fin. 16, 31 (1964).

33. J. Hicks, Value and Capital (2d ed. 1946), provides an alternative definition of personal income as increment in value. This definition can also be applied to corporations, but the value of the application is limited. Hicks suggests that income be measured as "the maximum amount which can be spent during a period if there is to be an expectation of maintaining intact the capital value of prospective receipts ....." Id. at 172-73. When this definition is applied to corporations, income becomes the maximum amount which could be distributed to investors (or just shareholders) during the period if there is to be an expectation of maintaining intact the capital value of prospective receipts. See Peterson, Significance of Prospective Income Data, 41 Accountunc REv. 275 (1966).

While the concept of the maintenance of capital is a useful tool for economic analysis, see generally Break, supra note 29 , it adds little to the Haig-Simons formulation for tax purposes. Where the two definitions differ, the former results in a purely hypothetical figure. If applied as of the beginning of the accounting period, the Hicks definition includes a hypothetical minuend: the excess of the capital value the enterprise (or just the shareholder's equity) was expected to have at the end of the period over its capital value at the beginning, adjusted for capital additions and distributions. See N. Kaldor, AN Expenditure TAX 62 (1955); Readings in the Concepts and MEAsurement of INCOME 5 (R. Parke \& G. Harcourt eds. 1969). If applicd as of the end of the accounting period, two formulations are possible. The first is simply the Haig-Simons definition: the excess of the capital value of the enterprise (or shareholders' equity) at the end of the period over the capital value at the beginning, adjusted for capital additions and distributions. See Solomons, Economic and Accounting Concepts of Income, 36 Accounting REv. 374, 376 (1961). The second requires a hypothetical subtrahend: the excess of the value of the corporate enterprise (or shareholders' equity) at the close of the period over its revised value at the beginning (as estimated at the close of the period) adjusted for capital additions and distributions. J. Hicks, supra, at 178-79. See also N. KALDOR, supra, at 67-68; Alexander, Income Measurement in a Dynamic Economy, in Five MonoGRAPHS ON Business Income 1 (Study Group on Bus. Income of the Am. Inst. of Accountants ed. 1950). The relevance of actual occurrences for tax purposes has generally led to the conclusion that such a hypothetical definition is not appropriate for defining taxable income. N. Kaldor, supra, at 69.70. See also R. Chambers, Accounting EvaluaTION AND ECONOMIC BEHAVIOR $117-19$ (1966); Alexander, supra, at 91-92; Bierman \& Davidson, The Income Concept-Value Increment or Earnings Predictor, 44 Accounting REv. 239, 244 (1969); Dean, Measurement of Profits for Executive Decisions, 26 ACCOUNTING REV. 185, 186 (1951), reprinted in CoNTEMPORARY ACCOUNTING AND ITS ENVIRONMENT 355 (J. Buckley ed. 1969).

34. Even assuming that the relevant increment in value accrues to the corporate enterprise generally, and not solely to shareholder equity, there is a final argument that some interest should be excluded from the ideal corporate tax base. Plumb, supra note 7 , at $627-28$. The cost of capital can be conceptualized as the sum of (1) the cost of using assets in a riskless enterprise, i.e., what it is worth to have something now 


\section{Accounting Income}

Financial reporting has never adopted periodic valuation as the means of determining income. ${ }^{35}$ Instead, accountancy has taken the familiar matching approach used in the statutory definition of taxable income, measuring income as the excess of revenues over costs for a particular period. There is, however, a superficial parallel between accounting income and the notion of income as increment in value: Accounting income, minus distributions to investors or owners, is the increase in net worth as revealed by a comparison of the figure in the balance sheet designed to reflect net worth at the end of the accounting period with that figure at the beginning of the period. ${ }^{36}$ Nevertheless, the parallel is misleading because the two concepts define corporate income quite differently. The realization criterion of accounting requires that historical, rather than current, costs be used in the reckoning. Gains due to changes in expectations, as well as expected gains, are not included in accounting income until they are realized; ${ }^{37}$ under the Haig-Simons definition of income unrealized gains would be included immediately. ${ }^{38}$

Since an accounting is necessarily made to some person or group, a point of view is always implicit in financial reporting. Not unlike the concept of increment described in the last section, accounting income or profit originally meant the addition to a proprietor's net worth which derived from the operation of a business. ${ }^{30}$ While that concept of income worked tolerably well in accounting for sole proprietorships and partnerships, the rise of the great corporations made measurement of corporate income for individual investors an impossible task because of the number and transience of investors in a single corporation. Thus the "entity" theory of accounting, in which the earnings

instead of in the future, plus (2) a premium for the risk entailed. V. BRUDNEY \& M. Chirelstein, supra note 17, at 63-65. Since even a riskless enterprise would necessarily incur the time preference component of the cost of capital in order to effect production, it might be concluded that payments for time preference reduce increment as much as payments for real, as opposed to financial, assets or services. That argument is, of course, inapposite with regard to the existing corporate income tax since the cost of equity capital also includes a payment for the riskless use of capital, but no deduction is permitted for any part of dividends paid. Moreover, interest on debt cannot be regarded as the rough equivalent of the cost of using assets in a riskless enterprise nor dividends on equity as the rough equivalent of a risk premium since equity instruments can be purchased independently of debt instruments. Thus, the return on equity instruments must include a pure time component as well as a risk premium.

35. See, e.g., Norris, Profit: Accounting Theory and Economics, in STUdies IN AcCounring 321, 325 (W. Baxter ed. 1950).

36. Solomons, supra note 33 , at 376 .

37. But see Alexander, supra note 33 , at 93.

38. See Solomons, supra note 33 , at $376-77$.

39. Vatter, Origins of the Fund Theory, in Contemporarx Studies in THE Evolution of Accounting Thought 95, 98-99 (M. Chatfield ed. 1968). 
of the corporation are measured and reported quite apart from investors' income, gradually replaced the proprietorship theory. ${ }^{40}$ Like the federal income tax system, accounting for financial reports early conceived of corporate income as a distinct and identifiable quantity.

The treatment of corporate interest payments has been controversial in financial reporting as well as in taxation because there remains the unavoidable question: To whom is the accounting made?41 The traditional answer has been that accountants are to prepare reports from the shareholders' point of view. ${ }^{42}$ Not surprisingly, net income under this view is defined as gross receipts minus operating expenses, taxes and interest expenses, since it is the remainder which is available either for distribution to the shareholders or for retention to increase their equity. This shareholder perspective has been regarded as controlling by the Accounting Principles Board of the American Institute of Certified Public Accountants, the body which authoritatively determined generally accepted accounting principles. ${ }^{43}$ Adherents of this view typically support their choice on two grounds-that stockholders are the legal proprietors of the corporation and that the reports are actually directed to the stockholders. ${ }^{44}$

For income tax purposes, however, neither of these reasons offered for adoption of the shareholder point of view is compelling. The analogy between stockholders and individual proprietors has already been rejected. And the corporate income tax return is definitely a report to the Treasury, not to the firm's own stockholders.

On the other hand, another view has persisted among accountants over the years, the view that because debtholders and stockholders both provide corporate capital, a more meaningful concept of corpo-

40. The leading exposition of the entity theory is W. Paton, supra note 12. Entity income has been criticized as meaningless because income is calculated for a nonexistent personality. Vatter, The Fund Theory of Accounting and Its Implications for Financial Reports, 17 Srud. Bus. AD. 1, 33 (1947). Other theoretical approaches to income definition which have been urged on the accounting profession include a "fund" theory, id.; a "residual equity" approach, Staubus, The Residual Equity Point of View in Accounting, 34 Accounting REv. 3 (1959); and "value added concept of enterprise income," Suojanen, Accounting Theory and the Large Corporation, 29 Accounting Rev. $391,395(1954)$.

41. S. Gilman, Accounting Concerts of Profits 95 (1939). See also B. Van Arkadie \&. C. Frank, Economic accounting and Development Planning 28-29 (rev. Am. ed. 1969).

42. W. Paton, supra note 12 , at 16,75 .

43. See Accounting Principles Board of the AICPA, Basic Concepts and Accounting Principles Underlying Financial Statements of Business Enteririses 10154 (1970) (statement no. 4). The Financial Accounting Standards Board succeeded the Accounting Principles Board in 1973 as the authoritative body for determining generally accepted accounting principles.

44. R. Sprouse \& M. Moonitz, A Tentative Set of Broad Accounting Principles TOR BUSINESS ENTERPRISES 37-38 (1962) (AICPA Accounting Research Study No. 3), defines owners' equity as "the residual interest in the assets of an enterprise." 
rate income measures the earnings of a business entity without regard to its plan of financing. ${ }^{45}$ Payments for wages, supplies and capital equipment are regarded as costs, but interest payments, like dividends, are considered distributions of profits rather than expenses of producing income. The point of view for such accounting shifts from the shareholders to that of operating management ${ }^{46}$ (if taxes are also considered a distribution) or to that of investors in the corporation generally (if taxes are considered an expense). ${ }^{47}$ The objective of accounting becomes recording and reporting "the activities of the firm with respect to the utilization of the assets entrusted to it by all outsiders," 48 i.e., shareholders and debtholders in the case of a corporation. Often called the net operating definition of income, ${ }^{49}$ this view carries the imprimatur of the American Accounting Association, ${ }^{50}$ a group mainly composed of accounting academicians. Its proponents argue that since financial reports today provide information to a variety of groups, such as government, management, unions, and the public at large, the income concept can best be used for interfirm and interperiod comparisons if it is defined independently of a corporation's financial structure. ${ }^{51}$

There is nothing inevitable, then, about the shareholder viewpoint. In the absence of some other reason to distinguish among corporations on the basis of their capital structure, the accounting definition of income-the nontax concept most closely corresponding to the statutory definition of corporate taxable income-provides no mandate for deduction of corporate interest payments.

\section{Corporate Income as Product}

Edwin Seligman, the early champion of an income tax, favored a corporate income tax base which included interest payments; at the same time, he thought interest should be deducted in measuring the net income of individuals. The concept of product-the output or yield of productive assets or activities-provides the basis for his definition

45. N. Bedford, Income Determination Theory: An Accounting Framework 181.84 (1965); W. Paton, supra note 12, at 266-68. But see Husband, The Entity Concept in Accounting, 29 Accounting Rev. 552, 560 (1954).

46. P. Mason, S. Davidson \& J. Schinder, Fundamentals of Accounting 281 (4th ed. 1959).

47. W. Paton \& R. Dixon, Essentials of Accounting 95-96, 121 (1958).

48. E. Hendriksen, Accounting Theory 31 (1970).

49. W. Paton, supra note 12 , at 259.

50. American Accounting Ass'N, Accounting and Reporting Standards for Corporate financial Statements and Preceding Statements and Supplements 5 (rev. ed. 1957).

51. S. Gilman, supra note 41 , at $93-94$. 
of income." "[I]ncome as a personal category" 53 requires the reduction of the net product by interest on a debt contracted to secure that product. Personal income is thus defined as "that which comes in to an individual above all necessary expenses of acquisition, and which is available for his own consumption."54 On the other hand, Seligman defines corporate net income as "total annual revenue from all sources minus all actual expenditures except interest and taxes." 55 Measurement of corporate income does not require the additional reduction since corporations are capable of only productive, not consumptive, activities. ${ }^{\text {*0 }}$ No deduction is to be permitted for corporate interest because debt and equity capital together represent the real assets of the corporation, its "earning capacity."

Seligman thus seems to suggest that corporate income can be defined as the earnings of corporate assets. This tax base would not correspond precisely with either a concept of income as increment in value (for not all increases in the values of assets would be taken into account) or with accounting income (unless the realization conventions of accountancy were adopted in full). Like those concepts, however, the view of corporate income as product provides no basis for interest deductibility since the value of the earnings of a corporation's assets is the same whether the assets are financed by the issuance of debt or equity instruments. 58 None of these concepts of corporate income ${ }^{59}$ provides a mandate for retaining the interest deduction; the discussion therefore turns to an examination of rationales commonly advanced for the corporate tax to see if the definitions of the corporate entity

52. E. Seligman, The Income Tax 12-13 (1914).

53. Id. at 19 .

54. E. Seligman, Essays in Taxation 246 (9th ed. 1921).

55. E. Seligaran, supra note 52 , at 19 .

56. Id. at 685. Seligman recognized that, strictly speaking, his position demanded a distinction between productive and consumptive credit in the case of individuals, but saw the difficulties of drawing that line in personal taxation. See also Moonitz, Should We Discard the Income Concept?, 37 Accountinc Rev. 175, 178 (1962).

57. E. Seligman, supra note 54, at 246. Similarly, if a tax were levied on propertythe forerunner of product as the tax base-rather than income, an individual's net worth (assets minus liabilities) would be the appropriate measure, while a corporation's property would be measured either by its assets or by the sum of its equity and debt. E. SELIGMAN, supra note 52 , at 513 .

58. See Tambini, Financial Policy and the Corporation Income Tax, in ThE TAXATION of Income From Capital 185, 186-87 (A. Harberger \& M. Bailey eds. 1969).

59. The concept of income is sometimes rejected as meaningless in the corporate context. See, e.g., Peloubet, European Experience With Value-Added Taxation, in AtTERnatives to Present Federal TAxes 64, 65 (Tax Institute of America ed. 1964); cf. $M$. Moonitz, The Basic Postulates of Accounting 16 (1961) (AICPA Accounting Research Study No. 1). If the point of income definition for tax purposes is to identify a fair tax base, the concept of fairness has also been rejected as inapplicable to corporate taxation. J. Chown, The Reform of Corporation TAx 9 (Institute for Fiscal Studies Pub. No. 2, 1971). 
implicit in any of them provide a satisfactory explanation for disparate treatment of interest and dividends.

\section{B. Rationales for the Separate Tax on Corporations}

\section{The Corporate Income Tax as an Adjunct to the Individual Income Tax}

Economists often observe that a corporation, unlike a natural person, has no taxpaying ability of its own, so that whatever tax is levied on a corporation in the first instance must ultimately be borne by natural persons. ${ }^{60}$ Therefore some think that considerations of equity justify a corporate income tax only to the extent necessary to reach the year's undistributed corporate earnings-earnings which would otherwise escape taxation under the realization criterion of the personal income tax. ${ }^{61}$ Accepting this position means adopting, for tax purposes, the fourth conception of the corporate entity, what remains after payments to all participants in the enterprise. That conception itself mandates like treatment of interest and dividend payments, here permitting both to be deducted in full.

But replacement of the current corporate income tax with a tax on undistributed earnings is extremely unlikely. ${ }^{62}$ Those who adhere to this rationale for taxation of corporations have therefore argued for a second-best solution, integrating the corporate and personal income taxes to minimize double taxation of corporate earnings. ${ }^{63} \mathrm{~A}$ number of suggestions have been made toward that end, three of which are relevant for the purposes of this discussion: ${ }^{04}$ provision for a credit

60. R. Musgrave, The Theory of Public Finance 173-74 (1959); 4 Royal [Canadian] COMM'N ON TAXATION, REPORT 4-5 (1966). See also Klein, Income Taxation and Legal Entities, 20 U.C.L.A. L. REv. 13, 39 (1972).

61. Pechman, Further Comments on CTB, in B. Bittker, C. Galvin, R. Muscrave \& J. Pechman, supra note 26, at 117; Klein, supra note 60, at 38; 4 RoXal [CaNAdian] CoMm'N ON TAXATION, supra note 60 , at $4-5$.

62. See p. 1609 infra.

63. To the extent that one accepts the argument that the corporate income tax is passed on to consumers (in the form of higher prices) or to workers (in the form of lower wages), the problem of overtaxation of shareholders disappears. See R. GoodE, supra note 12, at 44-72. The possibility remains that shareholders' income may be undertaxed relative to other kinds of income. For recent discussion of the incidence of the corporate tax, see note 138 infra.

64 . In order to achieve some integration, an individual taxpayer was permitted an exclusion of $\$ 50$ of dividends from gross income as well as a tax credit for 4 percent of the remainder of dividends received when the 1954 Code was enacted. Int. Rev. Code of 1954 , ch. $1, \$ \$ 34,116,68 \mathrm{~A}$ Stat. 13, 37. The exclusion was increased to $\$ 100$ and the credit repealed in 1964 . Revenue Act of 1964, Pub. L. No. 88-272, $\$ 201,78$ Stat. 31-32. Before 1936, integrated rates and a dividend exclusion were used to keep varying amounts of corporate earnings from being subject to both the corporate tax and the 
against shareholder taxes for corporate tax payments, ${ }^{65}$ provision for a credit against shareholder taxes for a percentage of dividends received ${ }^{66}$ and exclusion of dividends from shareholder income. ${ }^{67}$ Given the taxation of returns to equity capital at the corporate level, these proposals modify the taxation of shareholders so that, in general, income reached by the corporate tax is not also taxed at the shareholder level. ${ }^{88}$

Each of these second best alternatives would establish a corporate tax system which accords with the rationale under discussion and which maintains the deductibility of interest at the corporate level. This tempts one to conclude that conceiving of the corporate income tax as an adjunct to the personal income tax necessarily implies the deductibility of corporate interest, even if dividends are nondeductible. The temptation should be resisted, however, for the "adjunct" rationale is equally served by several other schemes, as long as interest and dividends are treated alike. For example, the corporation could be denied deductions for both interest and dividends paid, while shareholders and debtholders receive a credit against their own tax liabilities for tax payments made by the corporation on their behalf. While this plan would require debtholders as well as shareholders to compute their share of taxes paid by the corporation on corporate earnings, it would have whatever advantages follow from treating debt and equity identically at the corporate level. ${ }^{69}$ Similarly, debtholders could receive an exclusion or tax credit against their personal taxes for a percentage of the interest paid them by the corporation. Thus the practical second-best solutions offered to implement the view of the corporate income tax as an adjunct to personal income, solutions which are based on the assumption that dividend payments are not deductible, provide no guidance for solution of the problem at hand. As long as interest and dividend payments are not included in both

individual income tax. See generally Shoup, The Dividend Exclusion and Credit in the Revenue Code of 1954, 8 NaT'L TAX J. 136 (1955).

For current proposals for more substantial integration, see $R$. Goode, supra note 12, at 181-202; J. Pechman, Frderal Tax Policy 141-42 (2d ed. 1971). One possibility for integration not mentioned in the text, taxation of undistributed earnings to shareholders as is done currently in the case of partnerships, would eliminate the separate tax on corporations.

65. See Break, Integration of the Corporate and Personal Income Taxes, 22 NAT'L Tax J. 39 (1969).

66. A dividend credit for shareholders was part of the original Internal Revenue Code of 1954. Int. Rev. Code of 1954 , ch. $1, \S 34,68 \mathrm{~A}$ Stat. 13. See note 64 supra.

67. A partial exclusion for dividends received by individuals is found in Int. Rev. Code of 1954 , ch. $1, \$ 116,68 \mathrm{~A}$ Stat. 37 . See note 64 supra.

68. For a discussion of the effect of the shareholder's personal tax rate on the degree of minimization of the double tax, see J. PechMan, supra note 64, at 142-46.
69 . See pp. 1603-08 infra. 
corporate taxable income and the taxable income of security holders, the solutions are neutral with regard to which of these taxable units is to be allowed the deduction, exclusion, or credit.

\section{Other Rationales}

A separate tax on corporate income is sometimes considered appropriate because of the privileges and benefits granted corporations by the state, such as perpetual life, limited liability for investors, and marketability of shares. ${ }^{70}$ Under this view, the corporate income tax is an impersonal tax on doing business in the corporate form. ${ }^{71}$ The benefit rationale has been subjected to considerable criticism. ${ }^{72}$ But if it is accepted in spite of its defects, corporate income should be presumably defined to include returns to whoever benefits from the corporate form. Shareholders benefit since the return on their investment is possible only in the corporate context. Yet the same can be said for investors in many corporate securities, such as bonds, which pay a fixed return. Indeed, the amassing of capital and the development of certain enterprises made possible by the corporate form may also be of very great benefit to managers, employees, and suppliers.

Unless there were some way to distinguish among beneficiaries of the corporate form, the benefit rationale for taxation would therefore imply that a more expansive view of the corporate entity is required for tax purposes; it suggests defining the corporation as the aggregation of all participants in the productive enterprise and thus taxing returns that accrue to all of them. ${ }^{73}$ Rather than mandating maintenance of the interest deduction, such a definition implies that neither interest nor dividend payments should be deductible.

70. J. PeChMan, supra note 64, at 105-06.

71. Report of the Committee of the National Tax Association on Federal Taxation of Corporations, 32 NaT'L TAX Ass'N Conf. Proc. 534, 577-78 (1939) [hereinafter cited as Nat'l Tax Ass'n Rep.].

72. Criticism has centered on isolating the precise benefits and assessing their relationship to taxpaying ability. The benefits may be those accruing to business generally, such as governmental policies favoring expansion, id. at 537. If this is so, however, why limit the tax to corporations, particularly if the result is an inefficient allocation of resources between the corporate and noncorporate sectors? R. MusGRave, supra note 60 , at 177-78. If only corporate benefits are considered, the nexus between the special advantage conferred on corporations and taxpaying ability has been considered dubious on the theory that the availability of these legal privileges to all for the asking should reduce their monetary value to zero under free competition. Groves, Equity and Expediency in Business Taxation, in How Shall Business BE TAxed? 33, 37 (Tax Policy League ed. 1937); cf. Musgrave, Should an Absolute Corporation Tax Be Retained?, 40 Nat'L Tax Ass'N Conf. Proc. 111, 112 (1947). Finally, concession of the legitimacy of a special tax on corporations does not explain why the tax should be levied on net income as opposed to gross receipts, sales, or some other base. Nat'l Tax Ass'n Rep., supra note 71, at 565-68.

73. That conception has, of course, never been reflected in the statutory income $\operatorname{tax}$ base. 
Sometimes the separate tax on corporate income is defended as a great revenue producer, necessary to the maintenance of the modern public treasury. ${ }^{74}$ If that is the only rationale for the levy, there is considerable reason to deny all deductions, including those for payments for corporate capital, since the tax base would consequently be expanded and the revenue yield increased. Although revenue production can hardly be used as the sole, or even primary, guide to tax policy, that rationale provides no mandate for excluding debtholders from the corporate family.

A fourth argument for a separate tax on corporations has been located in the alleged need for control of corporate power ${ }^{75}$ or of "persistent monopoly elements in corporate profits." of the tax mechanism over direct regulation in ending whatever abuses are alleged is surely open to question, ${ }^{77}$ but even if those doubts were resolved in favor of the tax system, adoption of this rationale fails to provide a clear choice as to the appropriate composition of the taxable entity. If it is the amassing of capital which makes possible the undesirable aggregation of corporate power, payments for capital in whatever form provided should presumably be included in the tax base. Alternatively, if the tax were designed to reach only rents as economists define that term, here, the "difference between a firm's total revenues and its total costs," a deduction should be permitted for all costs, including the cost of capital, whether debt or equity. ${ }^{78}$ Without a clear conception of the social evil which supposedly inheres in the corporate form, this rationale thus fails to imply a definite choice regarding deductibility of payments for corporate capital. Neither of the alternatives suggested, moreover, offers support for differential treatment of interest and dividend payments.

In spite of the discriminatory effects often attributed to the corporate income tax, ${ }^{79}$ a number of economists have suggested that the tax might be justified by its economic effects. It has been argued that corporate income taxation is entirely compatible with the goals of fiscal policy, ${ }^{80}$ though that rationale suggests no basis for limiting the tax-

74. See, e.g., Slitor, The Corporate Income Tax: A Re-evaluation, 5 NAT'L TAx J. 289, 290 (1952).

75. R. MUSGRAve, supra note 60 , at 178 .

76. Slitor, supra note 74 , at 302 .

77. H. Groves \& R. Bish, Financing Government 178-79 (7th ed. 1973).

78. R. POSNER, supra note 12, at 230 . On the concept of economic profit generally, see Weston, The Profit Concept and Theory: A Restatement, 62 J. Pol. Econ. 152 (1954). 79. The tax is said to discriminate against the corporate sector, against capitalintensive activities within the corporate sector, and against equity capital among forms of capital. The TAXation of Income From Caprtal, supra note 58, at 2.

80. See generally R. Goode, supra note 12 . 
able entity to shareholders' equity. The tax has also been embraced as one of the built-in stabilizers of fiscal policy, helping to avert serious economic downturns and dangerous booms. ${ }^{81}$ As deductions for business expenses and interest restrict the corporate tax base to returns above fixed charges, deductibility may promote stabilization since the remaining tax base is likely to be more responsive to changes in business conditions than returns to assets in general. Even assuming its effect is thus leveraged, however, the absolute impact of the corporate income tax on stabilization may not be great. ${ }^{82}$ Unless that impact were significant, the case for the tax as a compensatory mechanism would not outweigh other arguments against the interest deduction. ${ }^{83}$

\section{Policy Conclusions and Summary}

The policies said to underlie federal income taxation of corporations fail to explain why interest is deductible in full from the corporate income tax. The adjunct to personal income taxation rationale comes closest. It provides a clear conceptual mandate, that only undistributed yearly earnings be taxed to corporations. Once that alternative is rejected as inconsistent with the present statute and unlikely to be realized in legislation, the second-best plans are neutral regarding choice of the taxable unit that may deduct or exclude payments for corporate capital. Viewing the corporate income tax purely as a benefit tax or as a revenue producer leads to the conclusion that payments for both debt and equity capital should be included in the corporate tax base. The other rationales ${ }^{84}$ for corporate taxation are less convincing as

81. A. Hansen, Economic Issues of The 1960s, at 140 (1960). See also Slitor, The Role of Corporate Income Taxation, 7 NaT'L TAX J. 227, 232-35 (1954).

82. J. Due \& A. Friedlaender, Government Finance: Economics of the Public Sector 337 (5th ed. 1973); Kust, Appraisal of the Corporate Income Tax, in Alternatives to Present federal Taxes 17, 20 (Tax Institute of America ed. 1964).

83. See pp. 1603-08 infra.

84. There are several other rationales for the corporate income tax which should be noted, although they are more problematic than those discussed in the text. With regard to public corporations, it has been argued that the tax can be justified on the basis of a "partnership principle": The government is seen as a sort of silent nonvoting partner which shares in the profits and, to some extent, the losses of the enterprise. Colm, The Corporation and the Corporate Income Tax in the American Economy, 44 AM. Econ. REv. 486, 495 (Supp. 1954). If the government's share can be viewed as a distribution of profits rather than as a cost, presumably the same is true of the share which goes to debtholders.

A variety of arguments have been made that corporations possess taxable capacity quite apart from that of individuals. While these assertions are typically worked out only imperfectly, none appears to mandate the interest deduction.

(1) The ability to pay taxes has been said to inhere in the productive activity of business organizations, just as it does in the consumptive ability of individuals. Sec Buehler, The Taxation of Business Enterprise-Its Theory and Practice, 183 ANNALs 96, 97 (1936). Adoption of a tax based on this assertion would not lead to differential treatment of debt and equity since assets are productive no matter how financed. A 
justifications for the tax itself and either fail to mandate clearly the appropriate definition of the corporate entity for taxation or suggest conceptions that would not distinguish the treatment of payments for debt and equity capital. Given the inclusion of shareholders in the corporate family, they thus provide no explanation for the different treatment accorded debtholders.

\section{The Case for Repeal of the Corporate Interest Deduction}

\section{A. The Case for Equivalent Treatment of Debt and Equity}

Judicial decisions have developed innumerable guidelines for implementation of the statutory distinction between debt and equity. ${ }^{85}$ At the extremes there is wide agreement on the definitions: the "classic debt is an unqualified obligation to pay a sum certain at a reasonably close fixed maturity date along with a fixed percentage in

prior governmental claim for its share of the return to assets prevents assertion of inability to pay taxes by a high debt firm on the grounds that all returns had been paid to debtholders. This rationale more logically supports a tax based on the rate of return to assets, Buehler, Ability to Pay, I TAX L. REv. 243, 255 (1946). For such a tax, see Blakely \& Zehms, $A$ New Look at the Corporate Income Tax, 20 TAx ExEc. 287 (1968). But see Morton, A Comment on "A New Look at the Corporate Income Tax," 21 TAx ExEc. 195 (1969).

(2) Large corporations have been said to possess a "higher capacity to pay taxes than small firms" because they (i) can average taxable income over a period of years, (ii) are better able to obtain capital from capital markets (and are therefore less dependent on reinvestment), and (iii) call for managerial investment decisions more likely to involve factors other than prospects of earnings from new ventures. Musgrave, supra note 72 , at $115-16$. If this rationale is used to tax at least some corporations, differential tax treatment should turn on the size of the firm, not its plan of financing.

(3) It has been suggested that the tax is justified on the ground that the corporation is a personality, not just in the eyes of the law, but that it is a real entity capable of paying taxes. R. Goode, supra note 12, at 25; Adams, Fundamental Problems of Federal Income Taxation, 35 Q.J. Econ. 527, 543 (1921). See also Studenski, Toward a Theory of Business Taxation, 48 J. PoL. EcoN. 621, 633 (1940). Embracing this rationale requires considerable faith in personification, but even true believers must concede that there are differences between corporate and natural persons which might justify differential tax treatment. Thus the rationale would call for a corporate interest deduction only if the reasons for permitting such deduction by individuals also applied to corporations, an application rejected at pp. $1589-90$ supra.

The argument has been advanced that the corporate income tax should be retained because it is an old tax and the burdens and benefits of an old tax will have been adequately capitalized by the market. R. GOODE, supra note 12, at 204-05; Discussion, 40 NAT'L TAX Ass'N CoNF. Proc. 120-21 (1947). This argument implicitly opposes any change in the tax structure whatsoever and must be rejected if discussion of reform is to be meaningful. The legitimate equity concern which underlies the argument can be met by the development of adequate transitional rules for any proposed change. See p. 1618 infra.

Finally, the corporate income tax has been thought to provide economic policymakers with additional tools for stabilization, such as the investment tax credit. Break, supra note 65, at 40 . Elimination of the interest deduction would not seem to preclude the manipulation of the corporate tax base for such policy purposes.

85. The cases are collected in 4 A J. Mertens, The Law of Federal Income Taxation \$§ 26.10-26.10e (1972); 2 S. SURREY, W. Warren, P. MCDANIEL \& H. AULT, Federal IN. CoMe TAXation 195-236 (1973); Plumb, supra note 7, at 370 n.8. 
interest payable regardless of the debtor's income or lack thereof." 80 Common stock with voting rights is the classic example of equity. The essential difference between debt and equity is usually said to be whether the funds are put at the risk of the business, with the equity investor foregoing a fixed return and insolvency priority in exchange for the residual interest and a greater degree of control over management. ${ }^{87}$ From these conceptions come a number of formal attributes which are said to pertain to one category or the other. ${ }^{88}$

That these differences disappear as the categories converge is well known: Subordinated debt is treated as equity by most institutional investors and other senior creditors; ${ }^{89}$ income bonds with a distant maturity date are difficult to distinguish from preferred stock, especially if dividends are mandatory when earnings exist. ${ }^{\circ 0}$ Equally familiar is the observation that differences in the terms of debt and equity investment contracts are less observed in practice than in theory. Management tends to view preferred stock much as it would bonds, paying the full dividend regularly as a matter of policy, ${ }^{01}$ while traditional creditors' rights on insolvency were long ago eroded by the development of reorganization remedies under federal bankruptcy law. ${ }^{92}$

Moreover, even where clear contractual differences do exist, debt and equity serve the same economic function for the corporation in that both provide financial capital, albeit at different costs depending on the terms of the investment contracts and the prevailing conditions in the relevant capital markets..$^{93}$ Today, investors and managers alike regard at least bonded indebtedness as a permanent part of corporate capital structure, not as a mere temporary borrowing. ${ }^{94}$ The job of the corporate financial manager is to use the alternatives of debt and equity in such a way as to minimize the cost of the firm's capital. ${ }^{95}$

86. Gilbert v. Commissioner, 248 F.2d 399, 402 (2d Cir. 1957) (Medina, J.).

87. Goldstein, supra note 7, at 3; Plumb, supra note 7 , at 404; Stone, supra note 7 , at 257.

88. See Plumb, supra note 7 , at 412-57.

89. Everett, Subordinated Debt-Nature, Objeclives and Enforcement, 44 B.U. L. REv. 487, 489 (1964); Johnson, Subordinated Debentures: Debt That Serves as Equity, $10 \mathrm{~J}$. FIN. 1, 2 (1955).

90. Comment, Bonds-Income Bonds-Rights of Bondholders and Deductibility of Interest for Federal Income Tax Purposes, 56 Mich. L. REv. 1334, 1339.40, 1351 (1958).

91. P. Hunt, C. Williams \& G. Donaldson, Basic Business Finance 366 (3d ed. 1966).

92. See Blum, The Law and Language of Corporate Reorganization, $17 \mathrm{U}$. CHI. L. REv. 565, 566 (1950). Accordingly, it has even been suggested that the added rights of bondholders under an indenture are of little significance. N. BUCHANAN, THE ECONOMics OF CORPORATE ENTERPRISE 132-35 (1940).

93. See V. BrudNey \& M. Chirelstein, supra note 17 , at $82-84,314-405$.

94. F. Thompson \& R. NorgaARd, Sinking Funds 37-38 (1967).

95. There is considerable dispute among financial theorists over whether the cost of corporate capital can actually be lowered by altering the debt-equity mix as conventional analysis suggests. The classic article, Modigliani \& Miller, The Cost of Capital, Cor- 
From the investor's point of view, debt and equity are also alternative means of providing corporate capital, with differences in risk, priority, maximum yield, and control determining the order of claims on future earnings of that capital. ${ }^{90}$

This identity of the function of debt and equity instruments forms the core of the case for equivalent treatment of interest and dividend payments. Since "interest and dividends both represent divisions of the net earnings on invested capital," ${ }^{97}$ disparate tax treatment results in an arbitrary differentiation of corporate income. ${ }^{98}$ Whatever contractual differences there are between debt and equity instruments, they are not decisive in defining the concept of corporate income, and they do not refute the argument for equivalent tax treatment of interest and dividend payments. ${ }^{90}$

A second argument for equivalent treatment of debt and equity arises from the litigation imbroglio generated by treating them differently. The fears that influenced Congress before 1918 were wellfounded. ${ }^{100}$ When the nontax consequences are slight, as in closely held enterprises, corporations and their investors have a powerful incentive to characterize an investment contract as debt in order to avoid taxation of corporate receipts at both the corporate and the investor levels. The resulting tidal wave of litigation has produced only confusion and a torrent of contradictory commentary. ${ }^{101}$ The Supreme Court has refused to face the issue in a quarter century, ${ }^{102}$ while Congress withdrew in 1969 by granting the Treasury Department power to end the confusion by regulation, ${ }^{103}$ a power the Secre-

poration Finance and the Theory of Investment, 48 AM. Econ. REv. 261 (1958), asserts that a firm's cost of capital is independent of its capital structure. The empirical results of this position are surveyed in S. DOBRovolsky, THE Economics of Corporation FINANCE 124-28 (1971). For arguments attacking this proposition, see J. VAN HORNE, Financial Management and Policy 159-61 (1968). The conventional analysis appears in $B$. Graham, D. Dodd \& S. Cottle, Security ANalysis 539-49 (4th ed. 1962).

96. Lent, supra note 8.

97. V. Brudney \& M. Chirelstein, supra note 17 , at 365 .

98. Lent, supra note 8 , at 141 . The theoretical equivalence of debt and equity has been widely accepted. See, e.g., A. BerLe \& G. MEANs, supra note 14, at 279; V. BrudNey \& M. CHIRELSTEIN, supra note 17 , at 82-84; H. Groves \& R. BISH, supra note 77, at 179; Baumol \& Malkiel, The Firm's Optimal Debt-Equity Combination and the Cost of Capital, 81 Q.J. ECON. 547 (1967); Linter, The Financing of Corporations, in THE CoRPORATION IN MODERN SocIETY 166 (E. Mason ed. 1959). But see Miller, The Corporation Income Tax and Corporate Financial Policies, in Stabilization Policies 381, 426 (Staff Report to the Comm'n on Money and Credit 1963).

99. See pp. 1589.98 supra.

100. See pp. 1585-86 supra.

101. See notes 7 \& 85 supra.

102. John Kelley Co. v. Commissioner, 326 U.S. 521 (1946) (last Supreme Court case on point). Subsequent denials of certiorari are collected in Plumb, supra note 7, at 370 n.8. 103. Tax Reform Act of 1969, Pub. L. No. 91-172, $\$ 415,83$ Stat. 613, adding $\S 385$ to the Internal Revenue Code. The House version of the Internal Revenue Code of 1954 contained a definition of debentures which was eliminated by the Senate in its 
tary has yet to exercise. Elimination of the debt-equity distinction would be the most efficacious method of eliminating the litigation imbroglio created by the as yet unrepealed temporary legislation of 1918.

A third argument for eliminating the distinction arises from the possible presence of tax incentives for debt financing under the current tax structure. While the litigation imbroglio has been largely limited to close corporations, ${ }^{104}$ both large and small corporations are said to benefit from the tax treatment of debt, the former because their aftertax cost of nonshareholder capital is reduced, and the latter (which may have only limited access to outside financing) because the double taxation of corporate returns is eliminated pro tanto by designating part of the shareholders' interest as debt. ${ }^{105}$ The lower net cost of corporate capital brought about by the deductibility of interest payments has thus been thought to bias capital structures in favor of debt, ${ }^{106}$ supposedly resulting in an inefficient unneutrality in the tax structure. ${ }^{107}$

Encouraging debt is usually considered undesirable for two reasons. First, a financial structure in which much of the capitalization requires payment of large fixed returns will be considerably more susceptible

criticism of the House's definition of the term "security." H.R. REP. No. 1337, 83d Cong," 2d Sess. A98-A100 (1954); S. REP. No. 1622, 83d Cong., 2d Sess. 42 (1954). Legislation was introduced in the House in 1959 creating safe harbors for debt instruments, but it also failed to be enacted. H.R. 4459, 86th Cong., Ist Sess. (1959). See also ALI FED. INCOME Tax Stat. $\$$ X500(g) (Feb. 1954 Draft): ABA Taxation Section, Recommendation No. 9, 81 ABA REP. 160 (1956); Hearings on Advisory Group Recommendations on Subchapters $C, J$, and $K$ of the Internal Revenue Code Before the House Ways and Means Comm., 86th Cong., lst Sess. 473, 501-02, 579 (Revised Report on Corporate Distributions and Adjustments 1958).

104. V. BRudney \& M. Chirelstein, supra note 17, at 364; Goldstein, supra note 7, at 5-6.

105. Plumb, supra note 7 , at 373. Comment, Stockholder Loans and the Debt-Equity Distinction, 22 STAN. L. REv. 847, $848-49$ (1970), suggests that closely held corporations are benefited more than public corporations because a stockholder of the former is willing to lend money in amounts and at interest rates not available to the latter in the capital markets.

106. See, e.g., S. Dobrovolsky, supra note 95, at 335-36; W. LEWELLEN, The Cost of Capital 32-52 (1969); D. Smith, Effects of Taxation: Corporate Financial Policy 12, 25-26 (1952); Brewer \& Michaelson, The Cost of Capital, Corporation Finance and the Theory of Investment: Comment, 55 AM. EcoN. REv. 516, $520-22$ (1965); Cook \& Cohn, Capital Structures of Electric Utilities Under the Public Utility Holding Company Act, 45 VA. L. Rev. 981, $997-98$ (1959); Hamada, Portfolio Analysis, Market Equilibrium and Corporation Finance, 24 J. Fin. 13 (1969); Howell, The Effects of Federal Income Taxation on the Form of External Financing by Business, 4 J. FiN. 203, 216 (1949); Johnson, supra note 89, at 10; Miller, Corporate Taxation and Methods of Corporate Financing, 42 AM. ECON. REv. 839 (1952); Modigliani \& Miller, supra note 95, at 272; Modigliani \& Miller, Corporate Taxes and the Cost of Capital: A Correction, 53 Ax. ECON. REv. 433, 438-42 (1963).

107. Groves, Preliminary Report of the Committee on the Federal Corporate Net Income Tax, 42 NAT'L TAX Ass'N CoNf. Proc. 437, 447.48 (1950). But see Slitor, supra note 74, at 298-301; Smith, Effects of Taxation on Corporate Financial Policy: $A$ Progress Report, 42 NAT't TAX Ass'N Cone. Proc. 69 (1950). 
to default and bankruptcy or reorganization when income fluctuates than will a structure with small fixed charges. Second, even if actual insolvency is avoided, the cure has been said to encourage socially undesirable activities such as speculation, ${ }^{108}$ undermaintenance of corporate properties, and reduction of wages or employment. ${ }^{109}$ As a result, experts in corporate financial policy have, since the 1930's, commended the efforts of state and federal regulatory bodies to reduce fixed charges to income and, at the same time, criticized tax incentives for debt. ${ }^{110}$

Although the nexus between the deductibility of interest from the federal corporate income tax and the encouragement of debt financing at first appears clear in theory, it has been somewhat difficult to establish as a matter of empirical fact. Among lawyers advising closely held corporations, it is apparently common knowledge that debt is substituted for stock largely for tax reasons. ${ }^{111}$ The effect of the tax differential on public corporations and the aggregate effect on corporate financing, on the other hand, have been more problematic. While corporate tax rates have risen substantially since the 1920's, and while there has been an increase in the ratio of corporate debt to equity in recent years, empirical studies have failed to reveal any significant effect of the tax system on debt financing. ${ }^{112}$ One such study found in examining individual cases, some influence of tax factors on corporate financial structure, particularly in the substitution of debt for preferred stock. But it concluded that the statistical evidence makes it difficult to justify elimination of interest deductibility solely on the

108. Rostow \& Cutler, Competing Systems of Corporate Reorganization: Chapters $\mathrm{X}$ and XI of the Bankruptcy Act, 48 YALE L.J. 1334, 1375 (1939).

109. H. Groves, Postwar Taxation and Economic Progress 31-35 (1946).

110. B. BITTKER \& J. Eustice, supra note 9 , at $\$ 4.01$. The possibility that the national economy could benefit from increased debt financing has not received a corresponding treatment. Id. In addition, the corporate interest deduction has been criticized in recent years as an inducement to corporate acquisitions. H.R. REP. No. 413, 9lst Cong., Ist Sess., pt. 1, at 102-03 (1969); Hearings on the Subject of Tax Reform Before the House Comm. on Ways and Means, 91st Cong., Ist Sess. 2404, 2419 (1969) (statement of Dr. Willard Mueller, Director, Bureau of Economics, Federal Trade Comm'n). As a result, the Tax Reform Act of 1969 added $\$ 279$ to the Internal Revenue Code, limiting the deductibility of interest on "corporate acquisition indebtedness." See also Sherman, How Tax Policy Induces Conglomerate Mergers, 25 NAT'L TAX J. 521 (1972).

111. B. BitTKER \& J. Eustice, supra note 9, at $\$ 4.02$. See also H. Groves, ProducTION, JoBS AND TAXES 25 (1944).

112. Lent, supra note 8, at 133-37; Miller, supra note 98, at 385-426. See also B. MOORE, AN INTRODUCtion To THE THEORY OF FinANCE 80 (1968); R. Goode, supra note 12, at 137; S. Kuznets, Capital in the American Economy 276.90 (1961); May, Cor. porate Structures and Federal Income Taxation, 22 HARv. Bus. REv. 10, 15 (1943); Silberman, How Much Can Business Borrow?, ForTune, June 1956, at 131; Sametz, Trends in the Volume and Composition of Equity Finance, $19 \mathrm{~J}$. Fin. 450 (1964); Schwartz \& Aronson, Some Surrogate Evidence in Support of the Concept of Optimal Financial Structure, 22 J. FIN. 10 (1967); Shapiro \& White, Patterns of Business Financing: Some Comments, 20 J. FIN. 693 (1965). 
basis of its discriminatory effects. ${ }^{113}$ Although the primacy of tax considerations can thus be identified in particular cases, ${ }^{114}$ students of finance have been unwilling to single out tax treatment as the cause of whatever increase in debt has been observed in general.115 Indeed, reexamination of the theoretical approaches to the problem produces models that regard the effect as having differing degrees of significance. ${ }^{116}$

In short, the effect that tax incentives have on debt financing is verified in certain specific cases, debated in the aggregate, and either straightforward or attenuated in theory depending on which model one chooses. To the extent that it is considered significant, the tax incentive for debt financing argues for elimination of the differential treatment of debt and equity. ${ }^{117}$

113. Lent, supra note 8, at 141. For similar conclusions regarding the substitution of debt for preferred stock in a particular industry, see Molloy, Federal Income Tax Aspects of New Trends in Railroad Corporate Finance, 12 TAX L. REv. 113 (1957).

114. See V. Brudney \& M. Chirelstein, supra note 17, at 355; J. Due \& A. FriedLAENDER, supra note 82 , at 336 .

115. R. Goode, supra note 12, at 138; J. Pechman, supra note 64; Tax Foundation, Inc., The CoRPorate INCOME Tax 62 (1968); Loomis, That Epic Corporate Bond Binge, ForTune, Feb. 1968, at 125; Personal Investing: An Oversupply of Stocks, Fortune, June 1970, at 171; The Morgan Guaranty Survey, The Anatomy of Debt, July 1966, at 3, 6 .

116. On the one hand, it has been asserted that focusing on the incremental (as opposed to average) cost of corporate capital over a substantial period leads to the conclusion that corporations do indeed expand their debt in accordance with the tax incentive to do so. Tambini, supra note 58, at 215 . On the other hand, cconomic models have been developed to indicate that when the preferential treatment of capital gains is taken into account, the combined effect of tax provisions further limits the cases in which the net tax incentive for debt is significant. While the corporate interest deduction may lead lower bracket shareholders to prefer a high corporate debt policy, the potential for deferral and the lower effective rate on capital gains may induce high bracket shareholders to prefer a low corporate debt policy. Farrar \& Selwyn, Taxes, Corporate Financial Policy and Return to Investors, 20 NAT'L TAx J. 444 (1967); Lintner, Dividends, Earnings, Leverage, Stock Prices, and the Supply of Capital to Corporations, 44 REv. Econ. \& STAT. 243, 267 (1962); Myers, Taxes, Corporate Financial Policy and the Return to Investors: Comment, 20 NAT'L TAX J. 455, 459 (1967; Stapleton, Taxes, the Cost of Capital and the Theory of Investment, 82 EcoN. J. 1273 (1972); Stiglitz, Taxation, Risk and the Allocation of Investment in a Competitive Economy, in STUDIES in The Theory of Capital Markets 294, 348-51 (M. Jensen ed. 1972) [hereinafter cited as Risk and Allocation]; Stiglitz, Taxation, Corporate Financial Policy, and the Cost of Capital, 2 J. Pub. Econ. 1 (1973) [hereinafter cited as Taxation and Cost]. See also S. DoBrovolsky, supra note 95, at 99.117; Miller, supra note 98 , at 429 n.37; Smith, supra note 107, at 73. Finally, it has been suggested that the disadvantages of potential bankruptcy offset whatever tax advantages militate for corporate debt. Baxter, Leverage, Risk of Ruin and the Cost of Capital, $22 \mathrm{~J}$. Fin. 395 (1967); Kraus \& Litzenberger, $A$ State Preference Model of Optimal Financial Leverage, 28 J. Fin. 911 (1973); Robichek \& Meyers, Problems in the Theory of Optimal Capital Structure, $1 \mathrm{~J}$. Fin. \& QuANr. ANAL. 1 (June 1966). See also Stiglitz, Some Aspects of the Pure Theory of Corporate Finance: Bankruptcies and Take Overs, 3 BELL J. EcoN. MGT. ScI. 458 (1972).

117. To the extent that the interest deduction currently encourages debt financing, repeal would presumably induce a shift to equity financing: neutrality at the corporate level, coupled with capital gains treatment of equity at the shareholder level, could have this effect. Equity financing would not involve financial dangers comparable to those inherent in too much debt. The effect of denying the interest deduction on corporate investment decisions is another matter. See pp. 1615-17 infra. 


\section{B. The Case for Repeal of the Interest Deduction}

The case for the equivalent treatment of debt and equity ultimately becomes a case for repeal of the deduction. The alternative solution, granting a deduction for dividend payments, is simply too remote to merit serious consideration. Enactment of such a deduction would mean that the corporate income tax would reach only the annual undistributed earnings of the corporation; the legislative history of revenue acts, the response of the business community to such a tax, and the large revenues produced by the present tax make such a change highly unlikely. Although this conception of the corporate income tax was partially implemented during the Roosevelt administration, ${ }^{118}$ repeal quickly followed. ${ }^{119}$ Corporate managers had experienced intense shareholder pressure to distribute earnings currently in order to reduce corporate tax payments, and this development was said to threaten economic growth. ${ }^{120}$ An alternative explanation is available for the business community's opposition to a tax on undistributed earnings: Management generally desires to avoid capital markets when internal funds are available for investment, ${ }^{121}$ and the pressure to distribute earnings if dividends were deductible would probably lead to increased reliance on capital markets for new funds. Finally, the great revenue productivity of the current levy makes congressional enactment of a dividend deduction for corporations an unrealistic expectation for tax reformers. ${ }^{122}$ Accordingly, this article now turns to an examination of the potentially adverse effects that repeal of the interest deduction might bring.

118. The Revenue Act of 1936, ch. $690, \S 14,49$ Stat. 1648, imposed a surtax on undistributed corporate profits. The surtax rate was graduated in accordance with the portion of corporation profits which were retained. Proposals to restrict the corporate income tax to undistributed earnings have received considerable academic support. See note 61 supra.

119. The Revenue Act of 1938, ch. 289, $\$ \$ 13-15,52$ Stat. 447 , greatly reduced the surtax rate on undistributed profits for 1938-39 and provided for its expiration at the end of 1939 .

120. See H.R. Rep. No. 1860, 75th Cong., 3d Sess. (1938); Sen. Rep. No. 1567, 75th Cong., 3d Sess. (1938).

121. R. GoodE, supra note 12 , at 196.

122. Plumb, supra note 7 , at 623 , 627. In 1973 the corporate income tax produced $\$ 39,045,309$ in tax revenues, accounting for 16.4 percent of all tax revenues. 1973 COMM'R OF INT. Rev. ANN. Rep. 89.

A final argument for repealing the interest deduction should be noted. Because interest charges are deductible from the corporate income tax, the impact of interest rates which are increased to achieve the goals of monetary policy may be weakened, A. BuRNs, Prosperity Without INFLATION 46-47, 53 (1957), though there is disagteement among economists as to whether the interest deduction actually interferes with monetary policy. See Miller, supra note 98 , at $432-35$. 
IV. Effects of Repeal of the Interest Deduction

\section{A. Alternatives to Debt}

Inclusion of interest payments in the corporate income tax base is sometimes opposed on the ground that such treatment might simply shift the focus of tax minimization by encouraging alternatives to long-term indebtedness, such as leasing and short-term borrowing. ${ }^{123}$ Put differently, if the concept of corporate income mandates the deductibility of operating, but not financial, charges, the former will be substituted for the latter. The short answer to this objection is that payments for the use of financial capital, which are disguised as payments for real goods or services, should be treated as are undisguised payments for the use of financial capital.

\section{Leases}

The advantages of leasing rather than purchasing assets under current accounting and tax rules have been extensively analyzed ${ }^{124}$ and need not be reviewed here except to indicate how leases should be treated if the corporate interest deduction were repealed. The purchase of a depreciable asset, with funds advanced by either debtholders or shareholders, would, after the repeal, give the purchaser a deduction for depreciation of the asset's cost and an investment tax credit if the asset qualified, but no deduction for use of the debt or equity capital. If instead of purchasing an asset the corporation entered into an arrangement such that it paid "rent" over the asset's lifetime, characterization of the transaction as a lease would permit the corporation to exchange the tax advantages of ownership (the depreciation deduction and investment tax credit) for a rent deduction which would include two components: the equivalent of principal payments for the asset and the equivalent of interest payments on indebtedness incurred to purchase the asset. Substitution of the first component of the rent

123. Id. at 626-27. See also Lent, supra note 8, at 140 .

124. See Baskes, Tax Planning for Lease Transactions, 1972 U. ILL. L.F. 482, 483; Cary, Corporate Financing Through the Sale and Lease-Back of Property: Business, Tax; and Policy Considerations, 62 HARv. L. Rev. I (1948); Davis, Tax Consequences of Leasing Transactions, 1962 U. ILL. L.F. 56; Gant, Illusion in Lease Financing, 37 Harv. Bus. Rev. 121 (March 1959); Goldstein, Equipment Leasing After the 1969 Act, N.Y.U. 29rH INST. ON FED. TAX. 1589 (1971); Meyer, Tax Aspects of Lease Transactions, 23 TAx Exxc. 616 (1971); Olson \& Wisniewski, Leasing: The Current Tax Picture in Rental of Industrial Facilities and Equipment, 29 J. TAx. 12 (1968); Robertson, Leasing ArrangementsFrom the Investor's Viewpoint, 46 Taxes 787 (1968); Vanderwicken, The Powerful Logic of the Leasing Boom, ForTuNe, Nov. 1973, at 132; Zeitlin, Tax Planning in EquipmentLeasing Shelters, $1969 \mathrm{~S}$. CAL. TAX INST. 621; Comment, Acquisition of Industrial and Commercial Equipment Through Leasing Arrangements, 66 YALE L.J. 751, 770 (1957). 
deduction for ownership tax consequences would result in a tax advantage for the lessee if (a) the asset were nondepreciable, (b) depreciation were allowable at a slower rate than the principal were amortized, or (c) the tax advantages of ownership were worth more to the lessor than the lessee, with the latter benefiting through a reduced rental rate.

These advantages of leasing do not depend on interest deductibility and already require a distinction between "leases" and "purchases" under the Code. ${ }^{125}$ Elimination of the interest deduction, and the corresponding creation of a tax advantage in the substitution of the second component of the rent deduction for interest, would not therefore create a new conceptual problem for the tax system. Determination that a lease transaction was actually a "purchase" would mean, under the principles developed in this article, that the lessee-owner could deduct depreciation and could use the tax credit for qualified assets, but could not deduct the interest implicit in the rental-purchase payments.

Even if a lease is not a disguised purchase, it might be argued that part of the rental is a substitute for interest. ${ }^{126}$ Suppose an asset with an expected lifetime of 30 years is rented for a 20-year term. Assuming the life expectancy of the asset is sufficiently long relative to the term of the lease (and the rental sufficiently low relative to the asset's fair market value) to preclude treating the lease as a purchase, should rental payments be deductible if interest payments are not? Unless some adjustment were made in the rental deduction, corporate debtors might rent real assets from would-be lenders instead of borrowing their money to purchase such assets. Alternatively, corporate lessors might actually be debtors making interest payments over the course of the rental period in the form of rental services, the value of which exceeds that of rent received at the beginning of the period. But conceding that rental payments or services, even in the case of a true lease, may be partial substitutes for interest does not require the conclusion that all rent or all costs should be included in the corporate tax base if all interest is. Instead, only that portion of the rent or costs which functions as interest should be denied deductibility. ${ }^{12 \pi}$

125. See, e.g., Starr's Estate v. Commissioner, 274 F.2d 294 (9th Cir. 1959); Baskes, supra note 124 , at 483 .

126. See R. Goode, supra note 12 , at 179-80.

127. The disparity that exists in the tax treatment of the purchaser and the lessor may seem unwarranted by the practical differences in the transactions: A person who "rents" an asset for its total useful life may be denied any rent deductions be. cause the transaction is seen as a disguised purchase; a person renting the same asset for a few years less than its useful life may receive deductions for all or most 
Identification of that portion will be easier if four cases are considered: (1) payment of rent for the use of a building or machinery as the asset is used, without a commitment to purchase more of such services over time; (2) a contractual commitment in period one to purchase goods or services in period two with payment in period one or two; (3) agreement at the beginning of a period of time to rent an asset for the period, but with payment in a lump sum at the beginning of the period; (4) purchase of rental services to be provided over time as in (3), but with payment also spread over the contract period.

In the first case, payments are made as the services are provided without a contractual commitment for the purchaser to continue buying, or the seller to continue providing, use of the rented asset. Thus the buyer purchases (and the seller sells) only real services, with neither paying anything for time preference or the risk of nonperformance. Similarly, payment in period two in case (2) would involve no interest payment from the buyer to the seller since the goods and the payment would be simultaneously exchanged. On the other hand, payment in period one in case (2) would imply an interest payment by the seller to the buyer since the price to the buyer in period one would be discounted to its then present value. The seller would, in effect, borrow cash from the buyer and would repay the loan with goods or services which are worth more than the principal amount. The excess over the principal amount of the loan is the equivalent of interest.

In the third case, a lessee might pay a single lump sum in year one for the right to use an asset for the next twenty years. Likewise, a corporation could pay a single lump sum for telephone or labor services to be provided over several years. Such a lump sum is the total of a series of present payments for future services, with each such payment equivalent to the individual prepayment discussed in case (2). Therefore, the lessee makes no payment for either time preference or to compensate the lessor for the risk it might not be paid in case (3). Rather, the prepaid lessor is, as in case (2), paying interest to the lessee over the term of the lease. It is as though the lessee had bought a

of his payments because the transaction would be regarded as a true lease. See p. 1613 infra. This disparity follows from the conceptual discontinuity between renting and owning an asset: Both the Internal Revenue Code and conventional accounting practices require that a particular transaction be made to fit one category or the other; there is no intermediate concept. Zeitlin, supra note 124 , at 642.43 , suggests that an intermediate tax concept is needed. He finds that the closest formulation is the accounting rule that certain borderline transactions may be treated as leases rather than purchases, but that their existence must be disclosed in a footnote to the financial statement. However, Zeitlin acknowledges that this formulation is not really useful for tax purposes. 
single premium term annuity from the lessor, who makes the annuity payments in the form of services rather than cash. Accordingly, none of the lessee's payments should be denied deductibility, while some component of the lessor's costs should be disallowed as interest if the lessor is a corporation.

In case (4), a corporate lessee also purchases the right to use an asset for a period of time, but pays for that right over the course of the period. From an investor's point of view it might be desirable to capitalize the series of future expenditures as a liability on the lessee's balance sheet, rather than adopt the more usual treatment of annual charges to income. ${ }^{128}$ For tax purposes, however, only the interest imputed as a part of this obligation should theoretically be disallowed. Since the term of the lease can be made the same as that in the lump sum payment case, the lessee can be assumed to bear the same risk of price fluctuations as in case (3), but its aggregate payments will necessarily be larger because of the deferral of rent and the risk of its default. That difference is not, however, equivalent to interest if the analysis above of case (2) is accepted. The annual payments by the lessee are simply a series of individual payments for services which are all contractually committed in advance. The difference between cases (3) and (4) arises not because the lessee borrows from the lessor in case (4), but because the lessor borrows from the lessee in case (3). Accordingly, the lessee should be permitted a full deduction for rental payments in case (4) unless those payments are deferred beyon'd the time at which the rented asset is used.

128. Cary, supra note 124 , at 12 n.28. The accounting treatment of leases is still a matter of controversy. Until very recently, generally accepted accounting principles required disclosure of material leases which involved "the right to use property and a related obligation to pay specific rents over a definite future period" and recordation as purchases of leases which were "clearly in substance installment purchases of property." Accounting Principles Board of the AiCPA, Rerorting of Leases in financial StateMents of Lessee 9 f 14 14-15 (Opinion No. 5, 1964). See also Accounting Principles Board of the AICPA, Accounting for Leases in Financial Statements of Lessors (Opinion No. 7, 1966); Commirtee on Accounting Procedures of THE AICPA, Accounting Research Bull. No. 43, ch. 14 (1953); J. Myers, Relorting of Leases in Financial StateMENTS (AICPA Accounting Research Study No. 4, 1962); Wyatt, Accounting for Leases, 1972 U. ILL. L.F. 497, 498-99.

Prodded by the Securities and Exchange Commission, the Accounting Principles Board has broadened the requirements of disclosure regarding noncapitalized leases for fiscal periods ending on or after December 31, 1973. Accounting Principles Board of the IICPA, Disclosure of Lease Commitments by Lessees (Opinion No. 31, 1973). Unsatisfied, the Commission has modified Rule 3-16 of Regulation S-X, 17 C.F.R. $\$ 210.3-16$ (1973), to require additional disclosure-notably of the present value of "financing leases" and of the impact on net income of such leases-for financial statements submitted to the Commission subsequent to November 30, 1973. 38 Fed. Reg. 29215 (1973). The end is not yet in sight because the Financial Accounting Standards Board (the successor to the Accounting Principles Board), to which both the Commission and the Accounting Principles Board had referred the problem of accounting for leases, has yet to speak. 
To recapitulate, leases which are actually purchases under existing rules would be treated as are undisguised purchases. Other leases may involve imputed interest for either the lessor (if a lump sum rental is received at the beginning of the lease term) or the lessee (if rental payments are deferred beyond receipt of rental services). The logic of this article would deny deductibility of only such imputed interest for corporations, not all rental payments. That result is not without precedent in the Code, ${ }^{129}$ and should be modified only when the administrative costs of imputation are greater than the gains.

\section{Short-Term Loans and Deferrals}

The analysis of the last section fails to consider the length of time a payment must be deferred before a portion can be considered interest. Disallowance of deductions for interest or long-term corporate indebtedness has been opposed because it would provide an incentive to shift financing to short-term debts which, though subject to renewal, should presumably be treated as operating charges. ${ }^{130}$ The same reasoning would apply to short-term deferrals which are not loans in form.

Yet if interest on long-term notes is to be denied deductibility, there is no logical basis on which to distinguish interest on shorter term notes or deferrals. Indeed, it is not altogether outrageous to characterize suppliers, who extend trade credit for 30 to 90 days, as providing corporate capital in exchange for an explicit or implicit financing charge. ${ }^{131}$ Similarly, employees who defer salary payments until after the end of a working period are, in effect, involuntary creditors of the corporation. ${ }^{132}$

In theory, the interest component which is implicit in such shortterm deferrals should not be deductible by a corporation, though isolation of such interest may not be worth the cost in many such cases. Perhaps a flat rule permitting deferral for a very limited period could be adopted, though the period should not be so long as to make attractive the creation of revolving credit arrangements as a substitute for longer commitments of capital. In any event, the theoretically

129. INT. REV. CoDE of 1954, $\$ 163(\mathrm{~b})$ imputes an interest charge in certain installment purchases of personal property or educational services. Section 483 provides that where no interest is stated in a deferred payment contract for the sale or exchange of property (or where the interest stated is substantially below the market rate) part of each payment must be treated as interest for tax purposes. Rev. Rul. 69-188, 1969-1 Cum. Bull. 54 held a "loan processing fee," sometimes referred to as "points," de. ductible as interest.

130. Lent, stupra note 8, at 140. See also Plumb, supra note 7, at 586 .

131. W. PAToN, supra note 12 , at 65-66.

132. Id. at $260-62$. 
correct solution, denial of all corporate interest deductions, should again be modified in practice only where the benefits of imputing interest are exceeded by the cost of imputation.

\section{B. Economic Efficiency}

\section{Allocation of Corporate Investment}

As noted in the discussion of tax incentives for debt financing, the deductibility of corporate interest is widely regarded as affecting corporate decisions on how to finance corporate investments. ${ }^{133}$ Moreover, the proposition that the interest deduction lowers capital costs has led to the conclusion that the interest deduction also affects corporate investment decisions. ${ }^{134}$ Projects which are profitable when the cost of debt may be deducted from a corporation's taxable income might not be profitable if tax costs were increased by the inclusion of interest charges in the corporate tax base. Accordingly, it has been argued that disallowing the interest deduction would lead to a reduction in the amount of corporate investment, ${ }^{135}$ perhaps inducing the substitution of labor for capital inputs. ${ }^{136}$

This asserted reduction assumes the corporate income tax is not shifted forward to consumers or backward to workers, ${ }^{137}$ although the actual incidence of the tax is widely disputed among economists. ${ }^{138}$ More importantly, if the corporate income tax does fall on corporate capital, ${ }^{130}$ it is not clear that the net effect of including interest in the

133. See pp. 1606-07 supra.

134. W. LEwelleN, supra note 106, at 32-52; Jorgensen, Anticipation and Investment Behavior, in Brookings QUarterly ECONOMETRIC MOdel of THE UNITEd States 35, 87 (J. Dusenberry, G. Fromm, L. Klein \& E. Kuh eds. 1965); Miller \& Modigliani, Estimates of the Cost of Capital Relevant for Investment Under Uncertainty, in DETERMINANTS of INVESTMENT Behavion 179, 186 (R. Ferber ed. 1967); Modigliani \& Miller, supra note 95, at 295; Modigliani \& Miller, supra note 106, at 440-41; Stapleton, supra note 116, at $1282,1288$.

135. V. Brupney \& M. Chirelstein, supra note 17, at 365; D. SMith, supra note 106, at 26.

136. See R. POSNER, supra note 12, at 230.

137. But see J. PeChMAN, supra note 64, at 120-21.

138. H. Groves, supra note 111 , at 27 , argues that denial of interest deductions would make it easier for part of the tax to be shifted to the consumer. For a sampling of the recent literature on the incidence of the corporate tax, see Cragg, Harberger \& Mieszkowski, Empirical Evidence on the Incidence of the Corporation Income Tax, 75 J. PoL. Econ. 811 (Supp. 1967); Gordon, The Incidence of the Corporation Income Tax in U.S. Manufacturing, 1925.62, 57 AM. EcoN. Rev. 731 (1967); Musgrave \& Krzyzaniak, Incidence of the Corporation Income Tax in U.S. Manufacturing: Comment, 58 AM. ECoN. REv. 1358 (1968); Oakland, Corporate Earnings and Tax Shifting in U.S. Manufacturing, 1930-1968, 54 REv. ECON. \& STAT. 235 (1972); Spencer, The shifting of the Corporation Income Tax in Canada, 2 CAN. J. ECoN. 21 (1969).

139. See Harberger, Efficiency Effects of Taxes on Income From Capital, in EFFEcTs of Corporation Income TAX 107 (M. Krzyzaniak ed. 1966), for an attempt to estimate the efficiency costs of distortion caused by differential taxation of corporate capital. But see Taxation and Cost, supra note 116 , at 33. 
tax base would be to discourage investment below the pretax level when other aspects of the corporate tax structure, such as accelerated depreciation and the investment tax credit, are considered. A pioneering analysis of corporate taxation and investment incentives concluded that interest deductibility coupled with one-year depreciation for debtfinanced assets would raise investment incentives above their pretax level; ${ }^{140}$ it does not necessarily follow that elimination of the deduction would discourage investment below the pretax level. Even if corporate investment would be reduced by including interest payments in the tax base, that result derives from the decision to levy a tax on corporate income in the first instance. Unless there were some reason to discriminate in favor of debt financing, ${ }^{141}$ whatever reduction in investment were thought undesirable could best be remedied by lowering the tax rate applicable to corporations. ${ }^{142}$

A more sophisticated version of the argument that repeal of the corporate interest deduction will distort the allocation of corporate investment is implicit in an economic model developed recently by Stiglitz. ${ }^{143}$ Accepting the proposition that in the absence of taxation the debt-equity mix has no effect on a firm's decisions as to projects in which it should invest, ${ }^{144}$ Stiglitz explores the possibility that taxinduced changes in financial structure also have no effect on these corporate investment decisions. He concludes that where bankruptcy is not a contraint, the corporate tax advantages which accrue from interest deductibility are offset by shareholder tax advantages, especially the possibility of deferring realization, which are peculiar to equity. Thus, a corporation's financial structure may be affected by the joint product of corporate and shareholder tax effects, but its optimal investment decision is unaffected by the present tax structure. When bankruptcy is introduced as a constraint, optimal decisions for a high debt firm in a world with corporate taxes differ from those which are optimal in a nontax world, but Stiglitz concludes that the distortion is not significant.

If the corporate interest deduction is necessary to maintain economic efficiency given the possibility of shareholder deferral of taxa-

140. Brown, Business Income Taxation and Investment Incentives, in INcome, EMployment And Public Policy 300, 314-15 (L. Metzler ed. 1948).

141. See note 110 supra.

142. L. Thurow, The Impact of TAxes on the American Economy $31-34$ (1971), summarizes econometric studies of the additional investment in plant and equipment produced by reducing effective corporate income tax rates. See also Lintner, Effect of Corporate Taxation on Real Investment, 44 AM. ECON. REv. 520 (Supp. 1954).

143. Taxation and Cost, supra note 116, at 1; Risk and Allocation, supra note 116, at 294.

144. See note 95 supra. 
tion on returns to equity, Stiglitz's analysis implies that elimination of the interest deduction might lead to inefficiency. The assumptions of his model-especially the postulates that losses can be completely offset under the tax and that depreciation allowances are equal to true economic depreciation ${ }^{\mathbf{1 4 5}}$-make this implication subject to some of the objections raised against the less sophisticated version of the inefficiency argument rejected above. If, on the other hand, the Stiglitz model is accepted as a close enough approximation of reality for policy purposes, the elimination of interest deductibility would have to be accompanied by one of two corollaries in order to avoid inefficiency. One would require that equity gains be taxed as they accrue rather than as they are realized; this procedure would tax gains to equity-holders in the same way that interest is taxed to debtholders. This alternative has been suggested several times as a general tax reform, ${ }^{146}$ but has never been enacted. The second corollary would require that interest be taxed to bondholders as equity gains are to shareholders. Since Stiglitz's model depends for its efficiency results on the ability of shareholders to defer taxation of capital gains on equity, and not on the availability of a preferential tax rate, nonrecognition of interest received might be extended to bondholders who reinvest the interest in comparable bonds of the same corporation. Such a provision has several analogues in the current Code. ${ }^{147}$ Thus, objections based on the Stiglitz model, which attempts to account for both personal and corporate tax provisions, could be overcome by providing for the nonrecognition of reinvested interest payments or the taxation of unrealized gains on corporate stock.

\section{Discrimination Against Incorporation}

It has also been suggested that denial of interest deductibility for corporations alone would result in discrimination in favor of unincorporated businesses, ${ }^{148}$ presumably creating a disincentive to incor-

145. Taxation and Cost, supra note 116, at 1, 2, 4. Economic depreciation and full loss offsets might, of course, be entirely desirable attributes of the income tax. See generally Taubman \& Rasche, Economic and Tax Depreciation of Office Buildings, 22 NAT'L TAX J. 334 (1969); Warren, The Deductibility by Individuals of Capital Losses Under the Federal Income Tax, 40 U. CHr. L. REv. 291 (1973).

146. See, e.g., Slawson, Taxing as Ordinary Income the Appreciation of Publicly Held Stock, 76 Y ALE L.J. 623 (1967).

147. If reinvested in comparable assets, taxation of gain is deferred when the receipts are from an involuntary conversion, INT. REV. CoDE of 1954, $\S 1033$, the sale of a principal residence, $i d$. $\$ 1034$, or the disposition of certain low income housing projects, id. \$ 1039 .

148. Miller, supra note 98, at 440. Stiglitz's model assumes that whether or not a firm incorporates is not affected by tax considerations, or if the decision is affected, that the resource allocation implications are not significant. Taxation and Cost, supra note 116 , at 33 n.38. 
porate. That a separate tax on corporate income, but not on the income of unincorporated businesses, discriminates against incorporation should surprise no one. If such discrimination is unwarranted, appropriate responses include broadening the tax base to business income generally ${ }^{149}$ or repeal of the separate corporate income tax. If a separate tax is to be levied solely on corporate income nonetheless, discrimination against incorporation would be minimized by an acrossthe-board reduction of the corporate tax rate, not by introduction of an additional discrimination against equity.

\section{Effect on Financial Stability}

Finally, immediate elimination of the deduction for corporate interest payments has been opposed because marginal firms might be plunged into bankruptcy and previously successful firms transformed into marginal ones. ${ }^{150}$ Prospective elimination has also been considered objectionable because it might discriminate against new businesses. ${ }^{151}$ The shock of withdrawing the interest deduction from corporate taxation and any potential discrimination could, of course, be mitigated by gradually phasing out the deduction over a transitional period. ${ }^{152}$

Even with such transitional adjustments, however, elimination of the interest deduction is bound to have a differential impact on corporate taxpayers. That some corporations will be relatively better or worse off than under the existing provisions is to be expected from almost any change in the statute. Such changes in position should be regarded as undesirable only if existing tax differentials are deemed preferable-a view precluded in this case by the foregoing analysis. The legitimate claim of reliance on an admittedly imperfect statutory structure can be discharged by adequate transitional provisions.

\section{Conclusion}

Originally conceived as a temporary concession to the World War I excess profits tax, full deductibility for corporate interest payments, coupled with the nondeductibility of dividends, has since been a per-

149. See generally Caplin, Income Tax Pressures on the Form of Business Organization: Is It Time for a "Doing Business" Tax?, 47 VA. L. REv. 249 (1961).

150. R. Goode, supra note 12, at 178; D. SMiTh, supra note 106, at 25-26; Ford, Some Economic Aspects of the Present Corporate Income Tax, 40 NaT'L TAX Ass'N Conf. Proc. 55, 60 (1947): Lent, supra note 8, at 140; Miller, supra note 98, at 439-40; Plumb, supra note 7, at 625. See also May, supra note 112, at 17 .

151. See Miller, supra note 98, at $439-40$; Plumb, supra note 7 , at 625 .

152. May, supra note 112 , at 18 . 
sistent problem of the federal tax on corporate income. The proprietorship differences between debt and equity on which differential treatment supposedly turns are dubious, and thus present no solution to the problem. The net income rationale for interest deductibility requires identification of a concept of corporate net income; when the available concepts, increment in value, accounting income, and the product of corporate assets, are examined, no corollary mandates the interest deduction. The rationales which are said to support the corporate income tax also provide little guidance as to the appropriate treatment of payments for corporate capital. Unless the current tax base were narrowed to undistributed earnings, the reasons given for taxing corporate income conclusively suggest only that such payments should be treated equivalently, in whatever form the capital is provided. The functional equivalence of debt and equity, the litigation imbroglio, and the tax incentives for debt (to the extent such incentives are significant) also argue for equivalent treatment of interest and dividends. Congress is extremely unlikely to enact a dividend deduction; such improbability transforms the argument for equivalent treatment into one for repeal of the interest deduction. Provision for adequate transitional rules, imputation of interest where administratively feasible, and similarity of realization treatment for shareholders and bondholders if required by considerations of economic efficiency could minimize any anticipated adverse effects of repeal while providing a more logical solution to the debt-equity dilemma. 